OPEN ACCESS

Edited by:

Janice Huber,

University of Alberta, Canada

Reviewed by:

Lenora LeMay,

University of Alberta, Canada

Jaime Fiddler,

University of Calgary, Canada

*Correspondence:

Shelley Tulloch

s.tulloch@uwinnipeg.ca

Specialty section:

This article was submitted to

Language, Culture and Diversity,

a section of the journal

Frontiers in Education

Received: 29 June 2021

Accepted: 17 January 2022

Published: 24 February 2022

Citation:

Tulloch S, Moore S, Lane J, Townley S, Dicker J, Boase D and

Adams E (2022)

Community-Anchored Assessment of Indigenous Second Language

Learning in K-12 Schools.

Front. Educ. 7:733047.

doi: 10.3389/feduc.2022.733047

\section{Community-Anchored Assessment of Indigenous Second Language Learning in K-12 Schools}

\author{
Shelley Tulloch ${ }^{1 *}$, Sylvia Moore ${ }^{2}$, Jodie Lane ${ }^{3}$, Sarah Townley4, Joan Dicker ${ }^{5}$, \\ Doris Boase ${ }^{6}$ and Ellen Adams ${ }^{7}$
}

${ }^{1}$ Department of Anthropology, University of Winnipeg, Winnipeg, MB, Canada, ${ }^{2}$ Faculty of Education, Memorial University of Newfoundland, Happy Valley-Goose Bay, NL, Canada, ${ }^{3}$ Department of Education and Economic Development, Nunatsiavut Government, Makkovik, NL, Canada, ${ }^{4}$ Retired Inuit Teacher, Curriculum Developer, Northwest River, NL, Canada, ${ }^{5}$ Retired Inuit Teacher, Nain, NL, Canada, ${ }^{6}$ Inuit Teacher, Hopedale, NL, Canada, ${ }^{7}$ Inuit Teacher, Rigolet, NL, Canada

Indigenous second language programs in K-12 schools contribute to culturally nourishing education and to the revitalization of Indigenous languages. Assessing Indigenous second language learning presents particular opportunities and challenges based on the linguistic, historical, political, cultural, and social contexts in and for which the Indigenous language is being taught and learned. The self-governing Inuit region of Nunatsiavut is concerned with developing effective and appropriate tools for assessing students' Inuttitut in order to evaluate how well K-12 programs are working so far, identify the basis on which future K-12 Inuttitut curriculum may be developed, and support ongoing assessment of learning and for learning in Inuttitut classrooms. This article discusses ways in which Inuit teachers in Nunatsiavut and a curriculum evaluation team have developed and implemented assessment tools and practices to evaluate Inuttitut learning in Nunatsiavut area K-12 schools. We discuss how Indigenous language learning and assessment, even when it occurs as part of an official school program, can be anchored in families and community. Families and communities need to be part of establishing language learning goals. Inuit teachers are drawing in full community resources and building a community of practice including Elders, other language speakers, leaders, principals, and teachers, to support and create contexts for community-anchored Inuttitut learning and assessment.

Keywords: community-based assessment, Inuit, Inuktitut, Nunatsiavut, indigenous languages, language revitalization, second language teaching and learning

\section{INTRODUCTION}

Indigenous second language programs in K-12 schools provide an important opportunity for children to learn and increase proficiency in Indigenous languages. Indigenous language programs in schools can contribute to culturally nourishing education. Such programs are also part of revitalizing threatened languages. Assessment of children's progress is key to an effective program curriculum developers need to know children's starting point to develop appropriate curriculum; teachers need to see what children are grasping, or not, and adjust their programs; and parents and funders want learning outcomes to be measured and communicated to them. Assessing Indigenous 
second language learning in schools presents specific opportunities and challenges based on the linguistic, historical, political, cultural, and social contexts in and for which the Indigenous language is being taught and learned.

When the Inuit self-governing region of Nunatsiavut began a review of the K-12 Inuttitut $^{1}$ curriculum being taught in Nunatsiavut-area schools, it asked, "What do our children in each grade level currently know in Inuttitut?" and, "After we revamp our Inuttitut curriculum, how can we assess ongoing progress in Inuttitut?" In response, a university-based team, partnering with retired and current Inuttitut teachers and with the Nunatsiavut Department of Education and Economic Development and the Ilisautiliuvik SuliaKapvinga Curriculum Center, developed and implemented two assessment tools to assess current levels of Inuttitut proficiency among K-12 students in Nunatsiavut area schools. The team also examined how Inuttitut language teachers are currently identifying, tracking and recording children's progress, their ideas for innovative assessment practices, and what they need in order to feel comfortable and competent implementing Inuttitut assessment.

Results from the Nunatsiavut K-12 Inuktitut Evaluation show that Indigenous language learning and assessment, even when it occurs as part of an official school program, needs to be anchored in families and community. Curriculum and assessment practices need to match community goals for the Indigenous second language program-creating new speakers of Inuttitut who are able and willing to use Inuttitut for everyday conversation in the community. Our work pointed to the value of drawing in full community resources, and building a community of practice including Elders, other language speakers, leaders, principals, and teachers, to support and create learning and assessment contexts, particularly as many teachers themselves are either Indigenous second language learners or Indigenous language speakers without formal teacher training.

In this manuscript, we start with a brief contextualization of teaching, learning, and assessing Indigenous language proficiency based on the current literature. We then move into a background on teaching and learning Inuttitut in Nunatsiavut schools, which draws on the published literature as well as the co-authors' personal experiences, personal communication, and unpublished/technical reports. We conclude with a discussion of how a community-anchored approach can support effective assessment of Inuttitut learning. A community-anchored approach is consistent with the goals of incorporating the Indigenous language in schools to provide culturally nourishing education and to support language revitalization efforts.

\section{ASSESSING INDIGENOUS LANGUAGE LEARNING OUTCOMES}

Assessment of a learner's language proficiency is key to an effective program. Effective assessment practices create

\footnotetext{
${ }^{1}$ Inuttitut is a dialect of the Inuit language, spoken in Nunatsiavut. The language is more broadly referred to as Inuktut, with specific dialects named in each region of the Inuit homeland.
}

opportunities to observe, document, or measure what is known at the beginning of a program, and what has been learned midway through, or at the end of a program. Assessment outcomes can be important to funders, program planners, curriculum developers, and teachers in evaluating how well a particular program or approach is working, what to keep doing, what to change, and identifying gaps that need to be addressed (e.g., Sims, 2008). Ongoing assessment is part of effective pedagogy, allowing teachers to build on what learners know, and to keep learning in the proximal zone (e.g., Peter and Hirata-Edds, 2006). Having concrete, measurable objectives is also part of effective lesson planning-knowing in advance where learners are trying to get to in a given lesson or unit, and presenting activities to support achievement of those learning outcomes. In contexts where Indigenous language learning has been marginalized, or treated as a trivial subject, assessment may also contribute to more positive attitudes about the legitimacy of Indigenous language learning programs.

Languages that are widely taught as second languages often have well established benchmarks of second language acquisition that can be the focal point of assessment. These may focus on accuracy in pronunciation, vocabulary, morphology, and grammatical structures. The focus on accuracy may reflect an ideology of language and literacy as decontextualized skills (something you have, or know), rather something that you do and practice (Street, 2003). Languages that are widely taught as second languages such as English, French, or Spanish have standardized, prescribed "correct" forms that are published in dictionaries and grammars, that can be taught and tested. However, many Indigenous (and other) languages do not have a prescribed standard.

Where there is not a standard, whose language does the teacher teach, and whose language do the learners need to speak in order to do well on assessments? Variation is inherent in all languages, whether it is regional variation reflected in different dialects, or variation over time, resulting in more and less conservative forms of the language, sometimes divided across age groups. Indigenous teachers, trained in western universities, may adopt a purist language ideology, focusing on correctness and a standard language. Inuit scholar PalluqCloutier's (2014) research with Inuit teachers in Nunavut, for instance, identified their general support for identifying a standard Inuktitut to teach, although they had differences of opinion about which dialect, or a combination thereof, should be the standard, as well as at which level (regional, territorial, etc.) the standard should apply.

However, a focus on correctness is not the only option. Linguists and teachers working with and teaching the endangered Corsican language in France tackled the question of how to teach and assess a language that had multiple dialects and no standard by adopting a polynomic standard, in which "good Corsican" is "negotiable, relative, and multiple" (Jaffe, 2003, p. 518). The intent was to focus on unity in diversity, community, identity, and belonging. Linguist Jaffe's (2003) analysis of these efforts showed that valuing, acknowledging, and teaching diverse forms of the language as equally correct is difficult, especially in a context of language loss where few speakers are highly proficient, and 
even fewer have knowledge of multiple dialects that would allow meaningful use of multiple varieties in the teaching and learning.

Where languages are undergoing attrition-reduction of the phonological, morphological, and syntactic complexity of a language due to language loss-the question of whether you teach, and assess, the language based on how people are actually speaking - the attritioned forms-or based on the more complete, more complex, older forms, is also raised. For example, in our work with Inuttitut in Nunatsiavut, we questioned whether our assessment should look for use of the dual grammatical marking, used in conservative Inuit dialects along with singular and plural markings, or accept the plural marking as correct when referring to two or more, as is common usage in Nunatsiavut.

Another option, rather than focusing on accuracy and language as a skill, is to focus on language as practice and functional competencies. In other words, ask "What are speakers able to do with the language?" Learning language, for many learners, is about learning culture and practicing being a member of a particular community. Brian Street (2003) writes, "literacy is a social practice, not simply a technical and neutral skill; that it is always embedded in socially constructed epistemological principles. It is about knowledge: the ways in which people address reading and writing are themselves rooted in conceptions of knowledge, identity, and being. It is also always embedded in social practices...” (pp. 1, 2). This is also true of language, overall. In many Indigenous language learning contexts, the goal is creating new speakers of a language, and this requires teaching (and assessing) all forms of language as culturally situated practices, not just isolated skills. Ojibwe scholar Patricia Ningewance's (2020) guide to teaching an Indigenous language, for example, includes concrete examples of lesson plans, with activities and assessment guides, which specifically target language learning as part of cultural practice and community participation. Melissa Borgia (2009), working with an Onön:dowaga: (Seneca) language and cultural school in New York State, also found that the most promising Indigenous language teaching and assessment practices are those which emphasized authentic, practical uses of the language.

Where Indigenous languages programs have developed benchmarks for learning and/or proposed and implemented assessment strategies, many of these are indeed focusing on functional and cultural learning outcomes. For example, the Northwest Indian Languages Institute (2010) has developed a series of benchmarks for Indigenous language learning that are focused on what the learner can do with the language. Similarly, the NETOLNEW language learning assessment tool (McIvor and Jacobs, 2016), designed for adult learners in communitybased programs, asks learners to self-assess based on what they can "always," "mostly," "sometimes," "rarely," or "not yet" do when using the Indigenous language. The Northwest Territories (2021) Indigenous language learning benchmarks explicitly acknowledge an "observing and silent phase" (p. 1), where learners may participate in Indigenous language interactions appropriately, without yet speaking the Indigenous language.

Some school-based programs explicitly incorporate community-based assessment activities. For example, Alberta Education's 9-year Cree Language and Culture Program includes "to form, maintain, and change interpersonal relationships" as a Grade 4 learning outcome, and the related assessment task is to greet, welcome, and seat Elders at a community event, while also introducing oneself (Alberta Education, 2008, p. 84). These assessment methods, paired with functional learning objectives, directly relate to community learning goals of producing speakers who can and will use the language in community. They are flexible enough to allow for language variation, i.e., different ways of using the language in order to reach the same goals.

Accuracy-based and functionally-based assessment are not necessarily mutually exclusive. Assessment practices can, and many do, assess both simultaneously. Effective communication requires a certain amount of accuracy and focus on form. However, assessment practices that focus on language in real use situations pay attention to how accurate pronunciation, vocabulary, and grammatical structures support effective communication (cf. Edmonds et al., 2013).

Assessment of Indigenous language learning does not need to target an individual's one-time, independent performance. Walkie Charles, a Yup'ik scholar, models dynamic language assessment in his Yugtun classroom. His assessments include interaction, with opportunities for learners to rethink and recast what they are saying, as an individual could in everyday conversation (Charles, 2011). He teaches new Yugtun teachers to draw on Yup'ik values, knowledge, and place to dynamically assess K-12 Yup'ik language learners (Coles-Ritchie and Charles, 2011). Different ideologies of languages, and the purposes for which they are learned, impacts learning goals, targeted outcomes, and the ways in which these outcomes are assessed.

In addition to considerations of which aspects of language should be assessed, and how these should be assessed, the endangered context of many Indigenous languages raises the question, who are the appropriate assessors of Indigenous language proficiency? In many cases, Indigenous language teachers are themselves language learners, and the fluent speakers-sometimes only Elders-are not necessarily trained in teaching or assessment methods (e.g., Moore and Tulloch, 2020). A few strategies that are being used are helping learners to self-assess (e.g., NETOLNEW self-assessment tool, and selfassessment templates in the Alberta 9-year Cree language and culture program); providing clear benchmarks for teachers who are learning alongside their students, and engaging Elders, community members, and other language experts who may not work in the language program per se, in the assessment process.

In Haynes, Stanfield, Gnyra, Anderson, and Schleif's 2010 review of promising practices in the assessment of Indigenous languages, the authors conclude:

(1) Local cultural practices should be an integral part of assessment design and delivery.

(2) Assessment tasks, methods, and scales should be adapted to the wide range of learners and contexts.

(3) Despite the challenges associated with assessment design, assessment implementation and adaptation should ultimately be community-driven (p. 3). 
The contexts in which Indigenous languages are being learned vary greatly, but fall within a general international framework and history of the oppression and suppression of Indigenous languages, resulting in language endangerment. Teaching and learning Indigenous languages effectively is a pressing need toward community goals of revitalizing, strengthening, and reawakening languages. Appropriate assessment strategies and formats are a key component of this teaching and learning (Ignace, 2016, p. 43).

\section{TEACHING AND LEARNING INUTTITUT IN NUNATSIAVUT}

Nunatsiavut Inuttitut teachers experience the above challenges in Indigenous languages assessment and are experimenting with community-based strategies for addressing them. A curriculum review in 2019-2020 opened doors for discussion of and incorporation of community-based strategies in Inuttitut learning and assessment in Nunatsiavut, as described below.

Nunatsiavut is made up of five Inuit communities on the north coast of Labrador. Inuit are an Arctic and sub-Arctic Indigenous people whose homeland stretches from Greenland to Alaska, and includes four land claims regions in Canada: Nunatsiavut, Nunavik (Quebec), Nunavut, and the Inuvialuit Settlement Region (Northwest Territories). About 90\% of Nunatsiavut's population, roughly 2,300 people, are Inuit. One in four Inuit in Nunatsiavut are able to carry on a conversation in Inuttitut, but these are mainly older adults, concentrated in Nunatsiavut's two most northerly communities (Statistics Canada, 2016).

For centuries, Inuit passed on Inuttitut to their children as a matter of course, as children spent their days with extended family, and the evidence of the children's learning was their ability to communicate effectively with the people around them. The first schools were established for Inuit children in the north coast of Labrador, by Moravian missionaries in the late 1700s (Procter, 2020). Missionaries taught in Inuttitut, the children's mother tongue. When Newfoundland and Labrador joined Canadian Confederation in 1949, the province mandated obligatory English-only schooling (Procter, 2020), and deliberately suppressed Inuttitut in Inuit children's schooling.

English-only led to the rapid decline in knowledge and use of Inuttitut (Mazurkewich, 1991). Children were spending the bulk of their days in another dominant language, and English started to replace their mother tongue (Dorais and Sammons, 2002). The educational policy caused a population shift which put Inuit and Settler families in closer and more sustained (and often antagonistic) contact, which also led to the decline of Inuttitut.

Co-author Sarah Townley described how these kinds of experiences as a student, and then as a young mom, in English-dominant schools and communities, negatively impacted Inuttitut's vitality:

...So a lot of that happened, and for me, I had my kids, I didn't want to speak in Inuttitut. It's because I was shamed of it, right? It seemed that English was our own - our main language or something. . So a lot of that happened in all the communities. So a lot of them [kids] are passive bilingual, like they are able to understand, but they just can't get the Inuttitut word out. So I calls it "just sleeping right now." It's going to be waking after a while now. Like when they want to start learning Inuttitut again, I know that it will be woken up, so they will be able to speak. ...'Cause like if you really want to learn Inuttitut, you could. . . Like even though I never spoke to my children, when they were growing up, I'm able to now with my grandchildren, so it makes a big difference (Sarah Townley, Northwest River, NL, 2014, personal communication with Shelley Tulloch).

The K-12 Inuttitut program emerged amidst efforts to reverse "the strong drift toward English" (Andersen and Johns, 2005, p. 202). Inuttitut was reintroduced in schools through the initiatives of the late Dr. Beatrice Watts, who was the first north coast Labradorian to earn a university degree and the first Labrador Inuit teacher. Starting in the 1960s, she developed an Inuttitut program in Nain, the most northerly Nunatsiavut community, and the one in which Inuttitut is still strongest. She was eventually hired to support Inuttitut programming, teacher training, and materials development for all of what is now Nunatsiavut. She guided the development and implementation of what was known as the First Language Program, starting in 1987 (Johns and Mazurkewich, 2001, p. 361). The Inuttitut First Language Program was offered for Kindergarten through Grade 3 in Nain, and for Kindergarten and Grade 1 in Hopedale (the next largest community, and the community with the next largest proportion of Inuttitut speakers, next to Nain). It is unclear how many of the children entering the program in its early years would have been learning Inuttitut at home (making it truly a first language program). Although the program is called "Inuttitut First Language," it appears to have been offered as an immersion/second language program, with the goal of revitalizing the language that was no longer widely used in Inuit homes. Teachers' accounts of the Inuttitut First Language program describe it as essentially the English language curriculum, which they were asked to translate and deliver in Inuttitut.

Beyond the first language/immersion program offered in the early years in two communities, which have now dwindled, Inuttitut was offered as a subject in schools in Nain, Hopedale, Makkovik, and Rigolet for between and 20 and 40 mins a day for primary grades and three 40 min periods in a 6-day cycle for grades 4-9. This core Inuttitut program continues to this day.

The comments from two retired Inuttitut teachers who taught Inuttitut in Nunatsiavut for 20 and 22 years, respectively, suggest Inuttitut was an ad hoc addition to the schooling, and the teachers had little in the way of materials, curriculum, learning benchmarks, or training in second language learning and assessment. As one retired Inuttitut teacher said:

I started teaching in the fall of ' 75 , and there was nothing there then. We had to do everything, basically from scratch. There was no curriculum at the time, so everything was whatever we made up, and whatever we chose to... whatever we chose to teach, or whatever we chose to develop. There was nothing when we first started. It was just right from your head. Do the best that you can.... They said okay we'd like you to come in and teach Inuttitut. Okay. And just do whatever you think the kids should learn. You know? Although there was some time that you would 
ask the other teachers, the English teachers, what should I be teaching? We sort of got guidance that way. What can we do? What would be helpful? For us, what would be helpful for us to teach them? Give us some ideas please because we didn't have anything [retired Inuttitut teacher, Nunatsiavut, quoted in Moore and Tulloch (2020), p. 17].

Another retired teacher described her experiences this way:

I didn't know what to do. I just had to follow the teachers. What do I start from? I had to learn my own way, I taught myself. I saw everyone doing this and doing that, no one told me to do this and do that, but I happened to just mimic them in this way... She told me to read books with them, watch them to make sure they say the right words in reading. But some of them can be. . not mixed up. . you know what I mean. Have fun with them, read with them. Make them understand. That's what we did.

Inuttitut is the most important to me, because mother tongue is the most important to speak to the kids, to understand it, to speak it. Kanuiven? How are you? Short little things first. And I used to go class to class to look at what they're doing, because they didn't teach me. They didn't tell me. I had to open up myself to be as a good teacher is supposed to be and I started learning [retired Inuttitut teacher, Nunatsiavut, quoted in Moore and Tulloch (2020, p. 17)].

About 55 years after Newfoundland and Labrador joined confederation and schooling was taken over by the province, an Inuit regional government (Nunatsiavut Government) was established in 2005 through the Labrador Inuit Land Claims Agreement. The Nunatsiavut Government has a mandate to preserve and promote the Inuttitut language. Through the Labrador Inuit Land Claims Agreement, the Nunatsiavut Government has the right to fully take over Nunatsiavut schools. For the moment, it is choosing to support Inuttitut and Inuit cultural education in the region by providing funding to the Newfoundland and Labrador English School District (NLESD) to deliver a K-12 Inuttitut language program and an Inuit cultural skills program. The Nunatsiavut Government also partnered with Memorial University to develop and deliver the Inuit Bachelor of Education Program (IBED), which offered embedded language learning and training in the linguistic description and analysis of Inuttitut.

Inuttitut education has come a long way in Labrador, from being the language used in the community and in the schools, to being completely marginalized, to now being rejuvenated and strengthened. The school has become a focal point of Inuttitut learning. New technologies, such as Rosetta Stone and other computer applications are making it easier to support language learning, even when the teacher is not fluent. However, as with all technology, the Rosetta Stone is quickly becoming dated (as it is CD-ROM based and many new computers are without the appropriate drive), therefore causing it to be used less frequently. Ilisautiliuvik SuliaKapvinga Curriculum Centre staff, who are Nunatsiavut Inuit, are actively working on materials and curriculum. Linguists, Inuit teachers, and community members have collaborated to make stories recorded by local speakers accessible to intermediate and advanced learners as pedagogical materials (Dicker et al., 2009). However, leaders, teachers, curriculum developers, parents, students, graduates and other community members are concerned that knowledge and use of Inuttitut continue to decline. At the time of the K-12 Inuktitut Curriculum Review, described below, decision-makers in the school were asking, "what are the outcomes of our K-12 Inuttitut program, and how can we improve them?" This article focuses on the aspects of the K-12 review related to assessment, with particular attention to the role that all members of the community-leaders, teachers, curriculum developers, parents, grandparents, students, graduates, and others-play, or could play, in Inuttitut learning and assessment.

\section{NUNATSIAVUT'S K-12 INUTTITUT PROGRAM EVALUATION}

In 2018, the Nunatsiavut Government initiated an evaluation of the current K-12 Inuttitut program in collaboration with the Newfoundland and Labrador English School District. Sylvia Moore (Memorial University) and Shelley Tulloch (University of Winnipeg), who are non-Inuit, university-based researchers coled the evaluation, assisted by Inuit Bachelor of Education student Joanne Voisey. Sarah Townley (Retired Inuit Program Specialist, Goose Bay) and Joan Dicker (Retired Inuttitut Teacher, Nain) co-led and implemented the Inuttitut proficiency assessment component of the evaluation. The review of Nunatsiavut's K12 Inuttitut program took into account the ways in which schools are currently teaching and assessing Inuttitut as a second language, as well as the broader context of language revitalization through Inuttitut in the schools. It attempted to answer the questions, "what is working well in teaching and learning Inuttitut in Nunatsiavut area schools and where are the gaps?" and "what is the current Inuttitut proficiency of students in Nunatsiavut schools?" Our research approach was developed in consultation with the Nunatsiavut Government and the Newfoundland and Labrador English School District, and received ethical approval from both, as well as from Memorial University's ethics committee.

The curriculum evaluation and proficiency assessments were collaborative and formative as the team worked with the Nunatsiavut Government Education Division staff, the Inuit Program Specialist, Ilisautiliuvik SuliaKapvinga Curriculum Centre staff, Inuttitut teachers, principals, students, and community members. The process was informed by Indigenous research methodologies, which privilege relationship, conversation, and holistic understanding. Our work originated in the expressed needs of the Nunatsiavut Government, which advised on and approved research methods. The individuals who conducted interviews, observation, and assessments have established and ongoing relationships with the Nunatsiavut communities and many of the participating teachers, principals, and local families. Our work relied on oral traditions through conversations with teachers, parents, and students and valued the thoughts, opinions, and lived experiences of those who participated. Observations, individual interviews, and community forums were open-ended, and created spaces for participants to tell their own stories of how 
they were experiencing K-12 Inuttitut education. Conversations addressed the history, context, and motivation of K-12 learning as well as pedagogy, materials, and outcomes. We engaged with communities before, during, and following the research, in particular with the Inuttitut language teachers and the Inuit Program Specialist, as well as with participants who checked their transcribed interviews and approved any quotations used in the report. We had intended to return to communities for in-person presentation and checking of preliminary results, but were not able to due to COVID-19 travel restrictions at the time we were finishing our report. Our team continues to work with Inuit teachers in professional learning to develop and share ideas and practices that emerged in the report. The final report was approved by the Nunatsiavut Government, which is currently working on its recommendations. Respect of Indigenous methods and Nunatsiavut ownership of the project from inception through reporting and implementation is essential as Inuttitut learning is part of Inuit sovereignty and self-determination.

Our team visited all Nunatsiavut area schools in the five Nunatsiavut communities in the Winter/Spring of early 2019. All currently practicing Inuttitut teachers and Ilisautiliuvik SuliaKapvinga Curriculum Center Staff (14 total), as well as seven former Inuttitut teachers participated in individual interviews and sharing of materials. All community members were invited to attend facilitated community discussions about K-12 Inuttitut teaching and learning through posters, radio announcements, and social media. Due to weather and other factors, a total of 11 current students, seven former students, and 19 parents and community members attended these meetings.

Data collection included a review of curriculum materials, teaching resources, observations of the language environment in the schools, individual interviews, community forums, and systematic language proficiency assessments, described below. For the observational component, Sylvia spent time with the Inuttitut program specialist, curriculum developers, and teachers in the Ilisautiliuvik SuliaKapvinga Curriculum Centre and teachers' classrooms. The staff and teachers guided her through the materials they were using, and with permission, she took some photos. During her 2 or 3 days in each school, Sylvia also paid attention to Inuttitut and English used over the PA system, on bulletin boards, and others. The curriculum materials collected were analyzed to identify which learning outcomes they targeted, which activities and materials were proposed, and which assessment tools or practices were suggested.

Interviews and community forums were open-ended conversations, following general themes. We asked Inuttitut teachers and curriculum developers about their experiences teaching and learning Inuttitut, what learning outcomes they were targeting and observing, their perceptions of the materials, resources, and strategies being used in K-12 Inuttitut teaching and learning, and their opinions of opportunities and challenges for K-12 Inuttitut teaching and learning, including the broader community context of Inuttitut revitalization. In the facilitated community discussions, themes included experiences and perceptions of K-12 teaching and learning of Inuttitut, desired and observed Inuttitut learning outcomes, and students' and parents' observations of successes and challenges in students' Inuttitut learning. Conversations took place in English and were audio recorded. Transcribed interviews were analyzed thematically by the university-based team members, who checked back regularly with the community-based team members and the teachers and curriculum developers to corroborate and expand on emerging themes. The consent process was described orally, as well as in a written consent form, which participants (or their parents/guardians, for minor) signed. Quotations from participants are used with consent, throughout the report and in thematic sections of this manuscript. Longer narratives from the two of the teacher participants who are also co-authors on this manuscript, are presented at the beginning of the results section to reflect the narrative nature of the research, and to ground the following thematic sections in a more holistic view of teaching and learning, from their experiences. The inclusion of named narratives by co-authors anchors ideas to faces and names in a way that gives the results credibility to Nunatsiavut readers, while keeping the remaining contributions anonymous in order to protects freedom of critical expression.

The Inuttitut proficiency assessments were conducted with students in Grades 3, 6, 9, and 12 in all five Nunatsiavut communities in the Fall of 2019. Joan Dicker and Sarah Townley, two retired Inuttitut teachers who are fluent in Inuttitut and hold Masters degrees in Education, conducted the assessments. Joan did the assessments in her home community of Nain, and in Makkovik where she has extended family. Sarah conducted the evaluations in Hopedale, Rigolet, and Postville-communities in which she is well known from when she used to travel as an Inuttitut curriculum consultant. Proficiency assessment included a self-assessment tool in which they indicated "agree" or "disagree" in response to a number of statements about Inuttitut learning and use. The assessors went through these forms orally with the students as a group, and students wrote their response on their own. The assessors also did a qualitative observational/interactive assessment with all the Grade 3, 6, 9, and 12 students who agreed, and whose parents had agreed, to participate in the assessment. Results from both were summarized and reported quantitatively. Our experiences in the development and delivery of these assessments, as well as what they were able to tell us (and what they were not able to tell us) about promising practices in Indigenous language assessment is described in more detail below.

Full results from all aspects of the K-12 Inuttitut Review are included in the 202-page Final Report submitted by Sylvia Moore and Shelley Tulloch to the Nunatsiavut Government in May 2020. In this article, we contextualize and analyze the results specifically as they relate to community involvement in the development, delivery, and assessment of K-12 curriculum and learning.

\section{MADE-IN-NUNATSIAVUT TOOLS FOR ASSESSING INUTTITUT PROFICIENCY}

The Inuttitut proficiency assessment developed and implemented for the K-12 Inuttitut review had multiple interrelated purposes. It provided a snapshot of where learners are currently at in 
their Inuttitut learning for the purpose of designing curriculum. It also provided insight into which types and degrees of proficiency the students are acquiring (or not). The process of designing, implementing, and reflecting on the effectiveness of the proficiency assessment tools was also a step in the process of understanding which methods of assessing Inuttitut learning outcomes might be appropriate in Nunatsiavut.

In developing the assessment, we considered other standalone tools that had been developed in similar contexts and/or with similar goals. We wanted the assessment process to be comfortable for the assessors and the learners, and for the learners to have a chance to show what they know and are able to do in Inuttitut. We also needed a process that was time efficient and could be completed without requiring too much of the assessors', students', and school's time.

We settled on a two-stage approach that combined self assessment with observational/interactive assessment. Proficiency indicators were adapted from benchmarks developed for K-12 Indigenous second language learners, including those developed by the Manitoba Education and Citizenship and Youth (2007) and Northwest Territories (2019), as well as those summarized in Haynes et al. (2010) review of Indigenous language learning assessment. We took into account what Sarah and Joan knew the students were likely to have had an opportunity to learn (or not). We workshopped the tools, once developed, with Inuttitut teachers in a professional learning meeting to get their feedback prior to implementation.

\section{Self-Assessment}

The self-assessment tool was modeled on a strengths-based "can do" tool developed by Indigenous scholars Onowa McIvor and Jacobs (2016), and influenced by promising practices in Indigenous second language assessment. The tool included 49 statements which addressed learner motivation and opportunities for learning as well as language proficiencies in four categories: receptive (e.g., understanding; non-verbal responses), interactive (e.g., conversation), extended productive [e.g. literacies as broadly defined by Balanoff and Chambers (2005)], and sociocultural (e.g., greetings, cultural vocabulary) [categories are adapted from Haynes et al. (2010)]. Sarah and Joan went through the statements with each class, asking the students to indicate for each item "no" (the statement did not yet describe them), "some" (the statement somewhat described them), or "yes" (the statement was true of them). Although we had hoped to give every Nunatsiavut student an opportunity to participate, school cancelations, scheduling, and other limitations resulted in only 125 students responding. These were primarily from Grade 3, 6, 9 , and 12, and from all five Nunatsiavut communities.

The self-assessment tool was easy to administer and to analyze results. We found that it was helpful in identifying overall trends in proficiency being obtained through the current K-12 Inuttitut curriculum. For example we found, and it was corroborated in the interviews and community forums, that the proficiencies being achieved tend to remain at the level of vocabulary and memorized, predictable utterances, that receptive proficiencies were higher than interactive proficiencies, and that students had difficulty moving from memorized phrases to spontaneous speech. The proficiencies that students are acquiring with most confidence are literacies and school-based practices, including sound-symbol correspondences in the Labrador Inuttitut writing system, reading familiar words, singing memorized songs, reciting memorized prayers, etc. (Moore and Tulloch, 2020) ${ }^{2}$.

In the section that asked about learning opportunities and motivation, we also observed that a majority of students felt that they had some opportunity to use Inuttitut outside of school, in the community, with friends, or at home, but that they were not always taking the opportunity when it was there. For example, $86 \%$ of students agreed ("yes" $-42 \%$ or "some" $-44 \%$ ) with the statement "I hear Inuktitut around the community", whereas a lower $70 \%$ agreed ("yes" - 28\%, "some" - 42\%) with the statement "I speak Inuktitut outside of school". We interpreted this as showing that there is a foundation upon which to build and strengthen home and community use of Inuttitut. The Inuttitut teachers suggested that the self-assessment tool, or a similar one, could be made available more widely to Nunatsiavut family and community members to stimulate reflexive thought and family dialog around language, and possibly to support learners and families in setting some of their own goals for language learning based on the functional descriptors in the tool's statements.

The self-assessment tool had a number of limitations. The statements have a range of interpretations in which different learners with comparable objective proficiency might rank themselves quite differently (for example, the statement "I use Inuttitut words for family members" could reflect a basic proficiency of referring to one's parents with Inuttitut terms, or a more advanced proficiency of naming all extended relatives with the appropriate Inuttitut kinship terms.) Some Inuit preservice teachers in the Inuit Bachelor of Education program also questioned the use of self-assessment for the purposes of grading or measuring achievement because they saw it as contrary to Inuit values of humility and not self-promoting.

\section{Interactive Assessment}

The second assessment tool was an interactive assessment based loosely on the Northwest Territories (2019) oral assessment of Indigenous language learning. The interactive assessment was administered one-on-one with the assessor and the student, and each assessment lasted about 10-20 mins. The assessors told each class, as a group, what to expect in the assessment, and then administered the assessment in Inuttitut, assessing students oneby-one in a private area. Again, the schools in all five Nunatsiavut communities participated, with a focus on students in grades 3,6 , 9 , and 12. A total of 124 students were assessed.

This assessment included greetings and introductions between the assessor and the student, viewing and responding to a picture from an Inuit illustrator (pointing, naming, questionanswer, and basic story-telling), basic reading (word recognition and pronunciation), and basic writing (translating words from English, filling in the blanks in an Inuttitut text) tasks. These tasks reflected what the assessors, experienced Inuttitut teachers, felt the students might have had an opportunity to learn in

\footnotetext{
${ }^{2}$ Complete results from the self assessment questionnaire are provided in Moore
} and Tulloch (2020). 
school. The assessors had a grid of proficiency indicators in each category, from which they assigned each student a numerical score between 10 and 18 [based on Northwest Territories (2019) oral proficiency scale], categorizing students as emergent, beginner, low intermediate or high intermediate/low advanced speakers, with various gradients within each category.

The assessment was able to give an overview of proficiency in each class grouping. For example, results showed most students in Grade 3 and Grade 6 at the emergent to beginner level of Inuttitut, with some achieving low to high intermediate proficiency by Grades 9 and 12. Results showed general trends of higher average proficiency at the higher grade levels, as would be expected, and they also showed a great deal of variation in proficiency from student to student, and from community to community.

Sarah and Joan both said that they found it very difficult to assign a number to the speakers. As Joan wrote following the assessment, "I found it really difficult to grade students by the scale from 10 to 18 as some students may be able to do really well in some areas [more] than others." In particular, both noticed that (some) students were either unable or unwilling to speak out answers in Inuttitut, even if they understood. Sarah summarized her observations of students in one of the strongest language communities saying, "They tried their best in responding back in Inuttitut, but more were comfortable in responding in English even though they understood a lot." Similarly, Joan said, "There are some students who are too shy to be heard trying to speak Inuttitut, even though I know they know it."

The implementation of this tool went smoothly. A part of its success is that it was administered by Joan and Sarah who are well-known, empathetic faces in the communities, who are proficient Inuttitut speakers and highly experienced Inuttitut second language teachers. Such individuals are rare in Nunatsiavut; finding someone with their language proficiency and teaching experience could be difficult to do this kind of one-on-one assessment on a regular basis.

A challenge in coming up with the proficiency indicators and both the assessment tools is that the kind of teaching and learning that is happening in the schools may not be the teaching and learning that Nunatsiavut communities really want to see in their children and youth. As the review of curriculum materials revealed, a lot of the school activity is focusing on vocabulary, pronunciation, colors, memorized phrases, etc., rather than interaction.

When developing the tool, we felt a tension between assessing based on what the students would have had a chance to learn in school (where they could experience success on the assessment), versus what the learning goals might be in a renewed K-12 Inuttitut curriculum that focused on interaction. Our understanding of what the children would have had a chance to learn was shaped by Sarah and Joan's decades of experiences teaching in the schools and developing Inuttitut curriculum, our initial consultations with Inuttitut teachers prior to the research, and data that had been collected in community forums up to that point (see method above, and results below), and our understanding of a desire for communicational outcomes was shaped by initial consultation with the teachers, and with the
Nunatsiavut Government. These challenges point to the need and opportunity for the Nunatsiavut Government, the Ilisautiliuvik SuliaKapvinga Curriculum Centre and the Inuttitut teachers to work closely with each other and with families and communities to articulate goals for the K-12 Inuktitut, from which teaching practices and assessment processes can flow.

\section{TEACHERS' EXPERIENCES WITH INUTTITUT LEARNING TARGETS, TEACHING, AND ASSESSMENT PRACTICES}

One of the findings of the K-12 Inuttitut curriculum review is that targeted outcomes are not yet explicit in the K-12 program. Jodie Lane, Nunatsiavut Government's Director of Education and a parent of children learning Inuttitut in Nunatsiavut area schools, articulates that from her perspective the primary goal for the K12 Inuttitut program is, or should be, creating new speakers, and a secondary goal is creating a passion and drive that will fuel language learning and revitalization:

I want speakers, and if we can't get speakers right away, I want the passion and the enthusiasm to come back. To make the way of learning better so that kids want to go [to Inuttitut class]. Not just got to go.... Ready to go, and keep on practicing and encouraging and talking to each other outside of school [quoted in Moore and Tulloch (2020, p. 21)].

Curriculum developers, teachers, parents, and students corroborated that they feel the goals of the core Inuttitut program should be conversation, communication, and creating speakers, but there is a disconnect between the big picture goal of creating speakers and any existing curriculum. In fact, most teachers for various reasons were not using existing materials and program guidelines. Either they are not aware it exists, or they find it difficult to use, or ill-adapted to their particular students' needs. This is consistent with some of the challenges identified in the literature on Indigenous language teaching and assessment (e.g., Okemaw, 2019). Some teachers, as a result, are instead creating lessons and materials and assessing on their own, using their own experiences and knowledge, and drawing in local values and communities. The experiences of two Inuttitut teachers from different communities are presented here as illustrative of the range of experiences among teachers. These two teachers are recognized by others in their school and community as having some success in supporting language learning, participated in the review and the consultations prior to and following, and have joined with the team as co-authors on this article.

\section{One Teacher's Story - Ellen Adams, Rigolet, and Nunatsiavut}

Ellen Adams is an Inuttitut teacher in Rigolet, a Nunatsiavut community that had a distinctive and now highly endangered dialect. Even among the older generation, there are very few if any mother tongue speakers remaining. She is a fluent speaker who has completed most of the course work toward a Bachelor of 
Education degree. She taught all the Inuttitut classes in the Rigolet school for many years and is widely respected for the work she does revitalizing Inuttitut.

When the research team visited Rigolet, she demonstrated the Inuttitut teaching resources that she uses. Some of these are her own original materials, and some are materials from Nunatsiavut's Ilisautiliuvik SuliaKapvinga Curriculum Centre which she has personally adapted into the Rigolet dialect. Her materials are organized by themes and grades. She also has created learning centers for younger students.

Ellen described her experiences with Inuttitut K-12 teaching targets, materials, and assessment saying:

There's not much of a curriculum. There really isn't... nothing to talk about. It's more lessons than an actual curriculum guide. For my K and 1, I use a book that has colors, numbers, animals, shapes, stuff like that. And I build off of that. And 2-3, I use the new Inuttitut picture book. . I It's pretty much the same thing as the $\mathrm{K}$ and 1, except it's more advanced and I add a little more detail to it. Then the 5 and 6, I usually flip between those two. I might do all about animals 1 year, and another year I'll do about families. So that we get all the details there. 7, 8 and 9 changes. There's nothing. . no set guidelines to follow, which makes it hard.

I usually teach just K-9 core Inuttitut, and about every 3 years, I teach high school Inuttitut. They have to have it to graduate. So every 3 years, I teach Grades 10-12, all together for Inuk.

I'm going by the skin of my teeth. If there was some book to tell us that by the end of this grade, you need to know this, I would love it. If you could develop something like that, it would be nice. But until that comes out, I'm just going to stick with this. Because I started with this one and it builds on to this one, and whatever I'm doing has to build on that one and build up again. I've got a system. It seems to work. But it's in my head, I haven't got it written down.

In Grades 7-9, we have modules and we have to pick out so many expressions in each module that they have to use in school and out. It is part of their. . I build it into their curriculum. It's supposed to be used everywhere. And they'll say "Miss, I said this today to this one" and "I said this today to that one."

We try to get Inuttitut out as much as we can. We have a spring concert coming up next week. We've got kids preparing for that. The girls are going to read speeches. The students in Grades 5 and 6 are doing a song. They picked the song themselves of course. What I like to do is take the music [that's available online]. . . kids will look at the videos, but there's no connection. So we'll take the song and we'll make our own video. So that you can relate to it.

I've done events myself where at Christmas time, we have a grandparents' tea. The kids invited their grandparents for something to drink. We sang Christmas carols and had a lunch. . . We sung Christmas carols in Inuttitut. A lot of English too, but we were together.

This year, for my success stories, they'd have to be that I took two kids to the Inuttitut speak-off who don't even take Inuttitut. They're in high school and they're not offered it this year, but they wrote their own speeches and went and did a wonderful job.

More professional development would be nice because we need to get together and share what we're doing with each other. We [went to other regions of Inuit Nunangat] twice since I've been working. It was really good, and one time a couple years ago, we had a meeting in Nain, where teachers from [other northern regions] came down and shared with us. That was really good. I loved that one. We went to Kuujjuaq, and we wanted to see how they kept it. It was really good.

Ellen is a very experienced teacher and an Inuttitut speaker who has developed her own mental system for evaluating students. She teaches all of the Inuttitut classes and knows all of the students, so is somewhat able to dynamically assess students and teach to their respective strengths and needs. Although there is next to no contextual support for Inuttitut in Rigolet, and Ellen finds it difficult to recruit Elders to come in and work with her class, she intuitively involves the community in her students' learning, and in their demonstration of what they have learned through concrete communicative events, from an Elders' tea to a formal speech competition (one of the favorite events throughout Nunatsiavut). Her experiences point to a desire for and felt need for Inuttitut learning to be anchored in the community, and some of the ways in which she involves community to create authentic contexts for language use and assessment.

\section{Another Teacher's Story - Doris Boase, Hopedale, and Nunatsiavut}

Doris Boase is an Inuttitut teacher with a different set of challenges and opportunities than those described by Ellen. She works in Hopedale, Nunatsiavut, where many of the older adults still speak Inuttitut fluently, and where students do have people outside of school with whom they can practice Inuttitut. Like most young adults in Hopedale, Doris describes herself as an Inuttitut learner, learning alongside her students. Doris has completed a Bachelor of Education degree in Memorial University's Inuit-specific B.Ed. cohort so has specific training to think outside the box and implement Inuit-specific pedagogies and assessment practices. She works within a team of four Inuttitut teachers who are fluent speakers, but who have limited teacher training. In her first year, she was assigned to teach the Grades 7-9 Inuttitut classes. In conversation and follow up email exchanges, Doris described how she approached assessment prior to learning, for learning, and of learning.

My first approach is to find out where they're at with their language, where they think they should be, and what topics or concerns they'd like to have dealt with, with regards to their language. The biggest part was general conversation. They felt that they were nowhere near close to even conversing with each other. So that was my focus right off the bat.

There's a routine that the grade 7 and 8 s had before I entered it. And that was to do the Lord's prayer in Inuttitut, sing Jesus Loves Me in Inuttitut, and sing Labradorimiut in Inuttitut. I learned through our Labrador Inuttitut Training Program course that singing was a huge way of getting them to familiarize themselves with the language structure. So... and right now, I'm using songs to help them loosen up their tongues. I picked this song in particular because it was written by students in Hopedale in the late 1960's. So I'm using the language for their language as well as something that's culturally appropriate to them, because the whole song is about activities that happened in Hopedale at that time. 
The elders play a huge part. The kids aren't ready to be speaking to them in conversation, but they can draw from them... not just the language, but other cultural aspects. Because for me, the language encompasses everything in our culture. And I think that the teaching in Inuttitut classes should be the same. The language overlaps everywhere.

There was good feedback when I took the grade 7 and 8 s out to build an igloo. I did that as one of my Inuttitut classes. We did it over three classes, I think, and the community received it well. I know igloo-building is not part of the Inuttitut language, like formal instruction, but I've told people and I also told my grade 9 students that you might be in an Inuttitut-teaching classroom, but from me you're also going to learn the cultural values of being Inuk. With the igloo building, I was throwing some Inuttitut into it, but it wasn't the whole focus. Another part was that they were learning something from their culture, a shelter. And they were also learning respect for the person who was teaching to build the igloo.

As an Inuk as well as an educator, I can understand and sympathize with how difficult it can be to formally assess a student's achievements as a learner of a second language.

Inuit are hands-on learners. Traditionally, we learn by doing. Inuit ancestors were not tested with paper and pencil on the correct technique to lacing up a Kamutik (wooden sled). They never gave exams that determined their skill or progress in learning their mother tongue.

Today, academics are based very much on paper. The ideal result of assessment for me would be giving a pass or fail. Today, however, percentages and numbers determine the success of a student. To accommodate the old and the new, I use both methods of assessment. Students are in ongoing assessment when it comes to language skills and comprehension. They are assessed on prior lessons, incorporating these into their current lessons. Repetition is important for learning a second language such as Inuttitut. You need to see it and hear it repeatedly to retain the information. Students are also given mini assignments and end-of-unit tests which are open-book tests. I do it this way so that learning Inuttitut is not stressful and so that formal testing does not deter them from wanting to learn.

In addition to bringing Inuttitut speakers into the school to enhance learning, Doris has also designed take-home language learning assessments that the students are to do with their families. Doris describes that her idea in these take-home assessments was to encourage families to use Inuttitut together at home, and to learn Inuttitut together. She also works in a school with strong leadership that supports a whole-school approach to Inuttitut learning, including morning routines in Inuttitut, posters around school, and whole school expectation to use Inuttitut phrases. Doris explains that she learned how to teach and how to assess through her formal training in the Inuit Bachelor of Education program, and through teaching role models in the Labrador Inuttitut Training program that she took concurrently: "A lot of the teaching I had... that we had from a couple of Inuttitut instructors specifically is how I approach my teaching and assessment." Her experiences also show the need for Inuttitut learning and assessment to be grounded in authentic communicational experiences, which include creating opportunities for students to engage with Elders and other community members as well as students and staff at the school in culturally relevant activities.

\section{NEEDS AND OPPORTUNITIES FOR COMMUNITY-ANCHORED INUTTITUT ASSESSMENT}

Ellen's and Doris' experiences, and those of other Inuttitut teachers point to needs and opportunities for developing and formalizing community-anchored Inuttitut assessment. Officially, the only standardized assessment of Inuttitut in the K-12 program are the report cards. Teachers indicate students' progress in three aspects of the Inuttitut program: communication in oral and written Inuttitut, use of language learning skills, and knowledge of Inuit cultures, using a 14 scale for grades K-6 and numerical/percentage grades for grades 7 and up. In conversation, teachers said they felt unsure how to evaluate students, often basing the assessment on the students' efforts or attitudes toward Inuttitut as the primary indicator of learning. They generally felt uncomfortable with the report card as decontextualized evaluation and suggested ways that they would prefer to collaboratively evaluate students, involving families and communities, or let students' performance and use of the language speak for itself. The following sections synthesize comments and observations from the K-12 curriculum observation that reflect communities', teachers', and students' perceptions of possibilities and promising practices in community-based assessment, supporting authentic language learning and building a community of practice around Inuttitut language use.

\section{Community-Established Goals for Language Learning}

In all aspects of the K-12 Inuttitut evaluation, students, parents, and other community members expressed strong motivation for the K-12 Inuttitut program to be part of revitalizing Inuttitut as an expression and reflection of Inuit culture and identity. Currently, the lack of (known) learning targets, benchmarks, and progressions in Inuttitut is a barrier, but it also reveals an opportunity for the Nunatsiavut Government, the Newfoundland and Labrador English School District, the Ilisautiliuvik SuliaKapvinga Curriculum Centre, teachers, students, and communities to come together to identify which language practices and aspects of Inuttitut are most valued, and which they want to target in a renewed K-12 Inuttitut curriculum. Community-established goals for language learning can help anchor learning in ways that will motivate K-12 Inuttitut learners, and that will make their learning success something to be celebrated in the whole community. Part of developing community-anchored goals for language learning might also include addressing whether the schools expect all students, in all communities, to hit particular learning targets in particular grades, or to whether a progress-based model is preferred [where students 
move through similar benchmarks, but at their own speed, such as has been adopted in the Northwest Territories (2019)].

\section{Assessment as Practice}

One of the most effective, and motivating, ways to demonstrate language learning is to use it for the functions for which it was learned. The students, teachers, and community members mentioned different ways that the learners were invited to showcase their Inuttitut learning. As Ellen's and Doris' experiences demonstrated above, one strategy is to teach everyday phrases in Inuttitut like "Hello," "How are you?," "Thank you," "I'm sorry," "May I go to the bathroom?" etc., and to encourage students (and all teachers and staff) to use these throughout the school, possibly reporting back to the teacher or self-assessing on how frequently and willingly one was using known phrases.

Students affirmed that interactional approaches were effective for reinforcing and demonstrating their learning. One student explained:

\begin{abstract}
We had to learn how to ask to go to our locker in Inuttitut and to the bathroom, to get a drink of water, to sharpen our pencil, get our headphones... any other basic things like that. Every day things... To get our headphones, she told us what the saying was and put it on the door, so whoever needed their headphones would have to say that to get them.... She'd go around the room and she would ask someone and they'd answer in Inuttitut and then that person would ask that same question to the next person and on and on like that. ...It used to be like are you feeling good today, or are you sick, something like that. Or like what's your name and then you would say uvunga, and then ask the next person. ... It really was [effective], because it helped us with our speeches then. Introducing yourself, like Atelihai, and going on like that, our grade, and... our hobbies and everything [quoted in Moore and Tulloch (2020, p. 37)].
\end{abstract}

As Ellen and Doris explained, above, these interactional approaches can be expanded to inviting community members for an event, and having the students interact appropriately with them, in Inuttitut.

Teachers are also using performances-concerts, for example-as opportunities to invite the community in and demonstrate the students' Inuttitut learning. Parents and students said they found these motivating. A favorite event, mentioned across the schools, is the yearly Inuttitut Speak-Off in which high school students prepare speeches in Inuttitut (often written by the student in English, translated by the teacher, and then memorized by the student) and compete in a speech competition. The top students from school travel to one of the five Nunatsiavut communities to compete in front of community-based judges. The students, teachers, families, and judges all considered these an opportunity for students to demonstrate and be proud of their achievements.

In some schools, students are preparing written work that includes Inuttitut, and these are being displayed in the school. These are other examples where the students' functional use of Inuttitut can be a form of assessment.

Other teachers are incorporating Inuttitut into other subjects such as Art or Life Skills (Inuit Traditional Skills, such as skin preparation, sewing, tool making, etc.). Teachers described a former teacher who taught Inuttitut through using it in meaningful tasks:

She wanted to make panitsiaks in the Home Ec. Room and speak Inuttitut while she was doing it. That kind of stuff. She wanted to go and take the kids to watch someone skin a seal and then take the seal meat and skin and come back and while she's doing all that, she's teaching Inuttitut too, right? She said that's how they do it up north and that was her goal [Quoted in Moore and Tulloch (2020, p. 44)].

The multi-modality in the approaches described is a promising practice in Indigenous second language learning (Parker Webster and John, 2013). The reading aloud, singing, and speeches are helping to develop strong sound-symbol correspondences and clear pronunciation of Inuttitut sounds and words. The comments from students, parents, and teachers raise the question, though, whether pronunciation and performance are being achieved as ends in themselves, without going the next step to creating speakers with spontaneous conversational proficiency.

\section{Bringing Learning Into Homes and Communities}

The events in the schools, and displays of children's work when parents visit the school, are some ways of involving parents in their Inuttitut learning. Comments from parents and students suggested that many are willing to be more engaged, either because they speak Inuttitut and can be resources for their children, or because they want to learn alongside their children. One Nunatsiavut parent, for example, told us, "I've sat up to the table and said, "Kanuiven" [How are you]? And they say, "What?" "Kanuiven?" ... [They] should know to answer me, "Kanuilaunga." A former student agreed: "I would also like the students to teach their parents what they know... Language is such a complex skill to learn and when you do not have someone there encouraging children every day in their everyday setting it will not stick. It is up to those caregivers in each child's life to challenge them to speak."

Some Inuttitut teachers told us that observing students talking to each other and to Elders was what they considered the most useful form of assessment. Joan suggested, based on decades of experience, that talking to parents about what their children are doing with Inuttitut would also be a good assessment strategy:

Where you had to write down if they can master this, or if they improved or anything like that. ...I didn't like to assess students like that. ... I think I would rather speak with the parents, rather than writing it all down, because the report cards... I found they didn't evaluate or assess the students the way it should be [quoted in Moore and Tulloch (2020, p. 54)].

Involving parents and community in students' learning is a way to make the most of the limited language resources in the community. Not everyone wants to be a teacher, but fluent speakers and retired teachers, especially in Nain and Hopedale, told us they would be willing to be involved in the K-12 program. Teachers also told us that they find parents are willing to support and/or learn alongside their children. 
Expanding the K-12 Inuttitut program outside the schools creates opportunities for authentic language use, and helps support the goal of creating a community of speakers who are using the language with one another.

\section{Land-Based Learning and Assessment}

One of the most frequently expressed desires of teachers, students, and community members was for more Inuttitut learning and assessment to take place on the land. Whether this means spring land camps or other outings at a distance from the school (such as the literacy camp Nunatsiavut sometimes holds), or just "outside" (such as when Doris' Grade 9 class learned to build an igloo), or in a simulated land experience in an Inuttitut tent in proximity to the school (as the Inuit language specialist suggests, below), teachers and learners feel that being outside, and on the land, creates more natural motivation to use Inuttitut.

In the K-12 Inuttitut review, one Inuttitut teacher said:

In an ideal situation, if we want to learn Inuttitut, we need to get out of the classroom, and I would love to see a class or students going out on the land even if it's up on the hill. And only speaking Inuttitut to the best of their abilities, but having the space to speak English to support themselves. But if you want to go back to your roots, you have to go back to your roots. And leave all the schools [quoted in Moore and Tulloch (2020, p. 39)].

Another speaker added:

Learning something they're going to be doing anyway - fishing, hunting, berry picking, cutting wood, whatever it's going to be. But bring the language into that. If you can apply language, it's going to stick, because that's what we know [quoted in Moore and Tulloch (2020, p. 39)].

A parent, former student, and pre-service teacher added this perspective:

Learning is very individual for the different towns. ... and a big thing is about the learning; genuine learning experiences in real life. So that the kids could see it right before them and hear it being talked about and maybe touching the things. Real learning experiences that way. And if it was culturally relevant, the lessons would stick better. Rather than just pencil and paper all the time [quoted in Moore and Tulloch (2020, p. 39)].

In Inuit communities, one of an individual's central relationships is to the land. Any opportunity to be on the land, and speaking in Inuttitut, reinforces the learning and the attachment to Inuit identity, community, and tradition (Mearns, 2017; Obed, 2017). An Inuit Program Specialist at the curriculum center expressed that while any interactive learning with Elders was desirable, being able to interact with Elders on the land was most effective:

I think the reason why it's difficult to bring the Elders in [to schools], is because you're transporting one or two people into a school that's already set in the classroom. The ideal thing is to for the students to go to the Elders. . . in a tent, or in the gym, or out on the land for land-based learning. But that has to be prepared. It has to be organized. Make sure the elders are okay, depending on their age. The time of year is another thing. Ideally, fall would be better. Spring is the best thing. Summer is good as well. It's the temperature. And then you have... you know it's a lot of work to preparing these things unless we have an area where it's just set for Elders, and is always there. And you can go there. It's always prepared. There should be staff to do it all the time, year round. No matter what season. Whether it's outdoors, based around the center of a resort, or I don't know what you'd call it. If there was a center like that, even outdoors in tents or set up in an area with cabins, or. . . and it's still outside, it's land-based, but it's set and it's staffed. It's a dream. I think it's the way it would work, but right now, I think the possibly easiest way is to have them come into the school, because you're in the classroom, and you can meet with them. It would help, but $1 \mathrm{~h}$ is not enough, obviously. But it would help a little [quoted in Moore and Tulloch (2020, p. 39)].

On the land learning, for now, is labor-intensive for the teachers as they do not have an established site where they can take the students. Getting institutional permission to take the students out can be a logistical hassle. Teachers say they experience administrative resistance to land-based initiatives (cf. Obed, 2017). One of the recommendations from the participants in the K-12 curriculum review, reflected in the report, was the establishment of a permanent place where students could go and speak Inuttitut with Elders and community members, whether a camp, or even a tent on school grounds.

\section{BEYOND K-12 - ASSESSING COMMUNITY-BASED LEARNING}

School-aged children and youth are not the only Inuttitut learners in Nunatsiavut. Developing community-based assessment strategies also holds promise for supporting community-based language programming. Nunatsiavut's Torngâsok Cultural Centre (now the Department of Language, Culture, and Tourism) released the Asiujittailillugit uKausivut: Language strategy in May 2012, with the goals to: "increase the number of Labrador Inuttitut speakers; support the use of Inuttitut by all ages; [and] significantly increase the visibility of Inuttitut" (Torngâsok Cultural Centre, 2012, p. 6). In 2005, Catharyn Andersen and Alanna Johns described communitybased initiatives that included a language nest program for preschoolers, adult learning programs, and train-the-trainer programs. Subsequent programming has involved Inuttitut coffee shops, where anyone can drop in and learn and practice conversational Inuttitut. Nunatsiavut's Department of Language, Culture, and Tourism's ongoing efforts to preserve, protect, and promote Inuttitut include non-formal learning programs such as the Master-Apprentice program, the Labrador Inuttitut Training Program, and Rosetta Stone online learning. It also supports community-based radio programming in Inuttitut, and provides translation services. A university-community partnership led to the creation of a community reference grammar (Johns and Nochasak, 2009) - a text that describes the structure of Inuttitut, specifically targeted to language learners. The Department of Language, Culture, and Tourism has recently released a new comprehensive language strategy.

One of the barriers to the continuation of communitybased programming has been an inability to assess learners' 
progress, and therefore to be accountable to funders and even the learners themselves. Collaboration in setting functional learning benchmarks for Inuttitut and strategies and communityanchored strategies or tools for assessing progress toward them appears to be a potential area for growth, both in the K-12 program and for adult learning. The Inuit Program Specialist for the Newfoundland and Labrador English School District, expressed a desire for closer collaboration between those working on K-12 programming and those working on communitybased programming: "Shouldn't we [school board's Inuttitut curriculum center, Nunatsiavut Government, and Torngâsok Cultural Centre] be on the same page and doing the same thing for the public, plus they should be helping us... they are helping us, but they should be... in our schools more? I don't know how to say it. There should be more communication, more collaboration, more..." [quoted in Moore and Tulloch (2020, p. 21)].

\section{CONCLUSION}

The curriculum evaluation and the proficiency assessments were two parts of an integrated study aimed at evaluating what is working and what is needed in Nunatsiavut's K-12 Inuttitut curriculum. The K-12 curriculum evaluation was grounded in the understanding that Nunatsiavut children are learning Inuttitut as a second language, that the Nunatsiavut Government and communities are committed to revitalizing Inuttitut, that the school has a role to play in language revitalization, and the perception that language learning and revitalization was not happening as quickly or efficiently as those funding, teaching, or learning in the program would have hoped.

Our analysis of proficiency assessments, curriculum materials, interviews and community forums confirmed gaps in and between the intended learning outcomes, and materials and strategies to achieve these, and the observed outcomes, and methods being used to assess these. Greater community engagement in setting learning goals, and practicing and assessing Inuttitut proficiency is aspired to as an anchor and support to Inuttitut learning.

School boards, schools, and teachers, have a vital role to play in the revitalization of Indigenous languages, but they cannot do it alone. As Jana Hacharek, an Inuit scholar and teacher in Alaska wrote, "the process of passing the language on needs to be a community-wide effort, not something that is left up to the schools" (Hacharek, 2003, p. 8). A community-wide effort includes reaching out to Elders and speakers, and mobilizing the "middle generation"- those who may not have had the opportunity to learn the language, or who may have lost it-to participate in creating a new community of speakers.

Programming to support teaching and learning Indigenous languages in schools and in communities has been in place since the 1970s for many Indigenous languages. However, the development of measurable targets for the Indigenous language learning, and even more so of appropriate methods and tools to assess what learning is taking place, is relatively new, and less well established. By default, some K-12 Indigenous language programs, such as Nunatsiavut's, are following what teachers, curriculum developers, and administrators know from English and French language arts, without specifically creating Indigenous languages programs that are anchored in the needs and desires of the community.

Effective assessment must measure the intended learning goals. Although not yet articulated in the K-12 Inuttitut curriculum, leaders and those involved in Nunatsiavut's K12 Inuttitut language program say they want its goal to be creating speakers-people who can and do use the language in the community. To this end, assessment strategies that include that real-life functions of the language, including outside of school, are appropriate. Some teachers are already doing so intuitively, and opportunities to share their practices, and develop new ones in dialog with other Indigenous language teachers, would be welcomed. Well trained and supported teachers, clear, measurable learning objectives, effective activities for reaching these objectives, and appropriate tools for measuring progress are all part of developing an effective K-12 Inuttitut curriculum that will be part of Nunatsiavut's goal of revitalizing their Inuttitut language.

\section{DATA AVAILABILITY STATEMENT}

The data analyzed in this study is subject to the following licenses/restrictions: Data referenced in this article is owned by the Nunatsiavut Government. Participants were assured anonymity and confidentiality. Requests to access these datasets should be directed to SM, Sylvia.moore@mun.ca.

\section{ETHICS STATEMENT}

The studies involving human participants were reviewed and approved by Memorial University Ethics Committee, Newfoundland and Labrador English School District Research Review Committee and Nunatsiavut Government Research Advisory Committee. Written informed consent to participate in this study was provided by the participants, and in the case of minors, by the participants' legal guardian/next of kin. Written informed consent was obtained from the individual(s) for the publication of any potentially identifiable images or data included in this article.

\section{AUTHOR CONTRIBUTIONS}

All authors listed have made a substantial, direct, and intellectual contribution to the work, and approved it for publication.

\section{FUNDING}

This inquiry was funded by the Nunatsiavut Government, Department of Education and Economic Development. 


\section{ACKNOWLEDGMENTS}

The K-12 Inuttitut Evaluation was conducted with the collaboration of the Newfoundland and Labrador English School District. We gratefully acknowledge their contributions, as well as those of the Inuttitut teachers, principals, curriculum developers, students, graduates, elders, parents, and other community

\section{REFERENCES}

Alberta Education (2008). Cree Language and Culture: 9-Year Program Classroom Assessment Materials, Grade 4. Edmonton: Alberta Education.

Andersen, C., and Johns, A. (2005). Labrador inuttitut: speaking into the future. Etud. Inuit Stud. 29, 187-205. doi: 10.7202/013939ar

Balanoff, H., and Chambers, C. (2005). Do my literacies count as literacy? An inquiry into Inuinnaqtun literacies in the Canadian north. Literacies 6, 18-20.

Borgia, M. (2009). "Modifying assessment tools for ganöhsesge:kha: hë:nödeyë:stha: a Seneca culture-language school," in Indigenous Language Revitalization: Encouragement, Guidance \& Lessons Learned, eds J. Reyhner and L. Lockard (Flagstaff, AZ: Northern Arizona University Press), 191-210.

Charles, S. W. (2011). Dynamic Assessment in a Yugtun Second Language Intermediate Adult Classroom. Ph.D. dissertation. Fairbanks, AK: University of Alaska Fairbanks.

Coles-Ritchie, M., and Charles, W. (2011). Indigenizing assessment using community funds of knowledge: a critical action research study. J. Am. Indian Educ. 50, 26-41.

Dicker, J., Dunbar, E., and Johns, A. (2009). "Developing intermediate language learning materials: a labrador inuttitut story database," in Indigenous Language Revitalization: Encouragement, Guidance \& Lessons Learned, eds J. Reyhner and L. Lockard (Flagstaff, AZ: Northern Arizona University), 155-166.

Dorais, L.-J., and Sammons, S. (2002). Language in Nunavut: Discourse and Identity in the Baffin Region. Iqaluit: Nunavut Arctic College and GEiTIC.

Edmonds, K., Roberts, N., Keegan, P. J., Houia, W., and Dale, H. (2013). Kaiaka Reo: Reo-â-Waha Ki Te Motu. The Development of Mâori Oral Language Proficiency Progressions. Final Report. Shastri Bhawan: Ministry of Education.

Hacharek, J. (2003). Defining the Role of the Iñupiaq Program: Recommendations for Initiating Reform. Barrow, AK: North Slope Borough School District.

Haynes, E., Stansfield, C., Gnyra, C. D., Anderson, S., and Schleif, M. (2010). Review of the Literature on the Assessment of Indigenous Languages. Prepared for the Bureau of Indian Education. Rockville, MD: Second Language Testing, Inc.

Ignace, M. (2016). First Nations Language Curriculum Building Guide. Vancouver, BC: First Nations Education Steering Committee.

Jaffe, A. (2003). Misrecognition unmasked? 'Polynomic' language, expert statuses and orthographic practices in Corsican schools. Pragmatics 13, 515-537. doi: 10.1075/prag.13.4.04jaf

Johns, A., and Mazurkewich, I. (2001). "The role of the university in the training of native language teachers," in The Green Book of Language Revitalization in Practice, eds L. Hinton and K. Hale (San Diego, CA: Academic Press), 355-366.

Johns, A., and Nochasak, C. (2009). "A community reference grammar of labrador inuttitut," in Proceedings of the 1st International Conference on Language Documentation and Conservation (ICLDC), Hawaii.

Manitoba Education and Citizenship and Youth (2007). Kindergarten to Grade 12 Aboriginal Languages and Cultures: Manitoba Curriculum Framework of Outcomes. Winnipeg: Manitoba Education.

Mazurkewich, I. (1991). Language maintenance in labrador: trying to hold the line. J. Atl. Provinces Linguist. Assoc. 13, 57-69.

McIvor, O., and Jacobs, P. (2016). NEDLNEW Language Learning Assessment Tool (v3.1). Available Online at: http://netolnew.ca/assessment/ (accessed June 1, 2021).

Mearns, R. (2017). Nunavut, Uqausivut, Piqqusivullu Najuqsittiarlavu (Caring for our Land, Language and Culture): The use of Land Camps in Inuit Knowledge Renewal and Research. MA thesis, Department of Geography \& Environmental Studies. Ottawa: Carleton University. members who shared thoughts, insights, and experiences that form the basis of this article. We also acknowledge the contributions of research assistant Joanne Voisey, and transcriber Rebecca Brennan. The process and results of this inquiry were initially reported on in an unpublished K-12 Inuktitut Review submitted to the Nunatsiavut Government, Department of Education and Economic Development.

Moore, S., and Tulloch, S. (2020). K-12 Inuktitut Evaluation: Final Report. Nain: Nunatsiavut Government.

Ningewance, P. (2020). Reclaiming our Territory, Word by Word: Grassroots Language Teaching. Lac Seul: Mazinaate.

Northwest Indian Languages Institute (2010). Language Proficiency Benchmarks | NILI. Available Online at: https://nili.uoregon.edu/language-proficiencybenchmarks/ (accessed June 1, 2021).

Northwest Territories (2019). Our Languages Curriculum: Territorial-Wide Pilot 2019-2020. Available Online at: https://www.ece.gov.nt.ca/sites/ece/files/ resources/our_languages_curriculum.pdf (accessed June 1, 2021).

Northwest Territories (2021). Draft Oral Proficiency Scale. Available Online at: https://www.ourlanguagesnwt.com/oral-proficiency-scale (accessed June 1, 2021).

Obed, D. (2017). Illiniavugut Nunami: Learning from the Land. Envisioning an Inuit-Centred Educational Future. MA thesis, Department of Atlantic Canada Studies. Halifax: Saint Mary's University.

Okemaw, V. N. (2019). Anishinaabemowin: Teachers' Practices in Manitoba. Ph.D. thesis. Edmonton: University of Alberta.

Palluq-Cloutier, J. (2014). The Standardization of Inuktut in the Education System in Nunavut [M.Ed.]. Charlottetown: University of Prince Edward Island.

Parker Webster, J., and John, T. A. (2013). "On becoming a "literate" person: making meaning with multiliteracies and multimodal tools," in Communities of Practice: An Alaskan Native Model for Language Teaching and Learning, eds P. E. Marlow and S. Siekmann (Tucsan, AZ: University of Arizona Press).

Peter, L., and Hirata-Edds, T. E. (2006). Using assessment to inform instruction in cherokee language revitalization. Int. J. Biling. Educ. Biling. 9, 643-658. doi: $10.2167 /$ beb385.0

Procter, A. (2020). A Long Journey: Residential Schools in Labrador and Newfoundland. St. John's, NL: ISER Books.

Sims, C. (2008). Assessing the language proficiency of tribal heritage language learners: issues and concerns for American Indian pueblo languages. Curr. Issues Lang. Plan. 9, 327-343. doi: 10.1080/14664200802139588

Statistics Canada (2016). Inuit: Fact Sheet for Nunatsiavut. Ottawa: Statistics Canada.

Street, B. (2003). What's "New" in new literacy studies: critical approaches to literacy in theory and practice. Curr. Issues Comp. Educ. 5, 77-91.

Torngâsok Cultural Centre (2012). Asiujittailillugit uKausivut: Language Strategy. Nain, NL: Torngâsok Cultural Centre.

Conflict of Interest: The authors declare that the research was conducted in the absence of any commercial or financial relationships that could be construed as a potential conflict of interest.

Publisher's Note: All claims expressed in this article are solely those of the authors and do not necessarily represent those of their affiliated organizations, or those of the publisher, the editors and the reviewers. Any product that may be evaluated in this article, or claim that may be made by its manufacturer, is not guaranteed or endorsed by the publisher.

Copyright (c) 2022 Tulloch, Moore, Lane, Townley, Dicker, Boase and Adams. This is an open-access article distributed under the terms of the Creative Commons Attribution License (CC BY). The use, distribution or reproduction in other forums is permitted, provided the original author(s) and the copyright owner(s) are credited and that the original publication in this journal is cited, in accordance with accepted academic practice. No use, distribution or reproduction is permitted which does not comply with these terms. 